\title{
Analyzing the relationship between water pollution and economic activity for a more effective pollution control policy in Bali Province, Indonesia
}

\section{Saroj Kumar Chapagain ( $\sim$ saroj@unu.edu )}

United Nations University Tokyo: Kokuren Daigaku https://orcid.org/0000-0002-7348-2085

\section{Geetha Mohan}

United Nations University Tokyo: Kokuren Daigaku

\section{Andi Besse Rimba}

Shibaura Institute of Technology - Toyosu Campus: Shibaura Kogyo Daigaku

\section{Carolyn Payus}

United Nations University Tokyo: Kokuren Daigaku

\section{Made Sudarma}

Udayana University: Universitas Udayana

\section{Kensuke Fukushi}

United Nations University Tokyo: Kokuren Daigaku

\section{Research Article}

Keywords: Biochemical oxygen demand (BOD), Bali, Environmentally extended input-output (EEIO) modeling, Direct pollution, Water policy, Water pollution

Posted Date: July 12th, 2021

DOl: https://doi.org/10.21203/rs.3.rs-604424/v1

License: (c) (1) This work is licensed under a Creative Commons Attribution 4.0 International License. Read Full License

Version of Record: A version of this preprint was published at Sustainable Environment Research on January 11th, 2022. See the published version at https://doi.org/10.1186/s42834-021-00115-6. 
Analyzing the relationship between water pollution and economic activity for a more effective pollution control policy in Bali Province, Indonesia

4 Saroj Kumar Chapagain ${ }^{1 *}$, Geetha Mohan ${ }^{1,2^{*}}$, Andi Besse Rimba ${ }^{3}$, Carolyn Payus ${ }^{1,2,4}$, I Made

${ }^{1}$ United Nations University, Institute for the Advanced Study of Sustainability (UNU-IAS), 5-53-

8 2'Institute for Future Initiatives, University of Tokyo, 7-3-1 Hongo, Bunkyo-Ku, Tokyo, 113-

$11{ }^{4}$ Faculty of Science \& Natural Resources, Universiti Malaysia Sabah, 88400, Kota Kinabalu,

$13{ }^{5}$ Centre of Environmental Research, Udayana University, PB Sudirman, Denpasar, Bali, Indonesia

$15 *$ Correspondence: saroj@unu.edu; geetha.mohan@unu.edu 


\section{Abstract}

17 An adequate water supply is essential for the continued and sustainable growth of the Balinese

18 economy. In addition to mounting water demand, Bali's water supply has been compromised by

19 high levels of water pollution. Despite being paid great attention, Bali's earlier efforts to control

20 water pollution yet to prove effective, mainly owing to their reliance on traditional methods and

21 regulations that focus on water pollution being linked to discrete sets of economic activity (e.g.,

22 processing industries, livestock farming, and hotels). However, all economic sectors are

23 interconnected through supply chains; thus, water pollution is the combined result of all sectors'

24 environmental performance. Therefore, determining the structural relationships between water

25 pollution and economic activity serves as an important basis for more effective forms of

26 pollution control for the Balinese economy. In this study, accordingly, we employed an

27 environmentally extended input-output model to establish the links between water pollution and

28 the production processes of the entire economy. Using biochemical oxygen demand (BOD) as a

29 proxy for water quality in our analysis, we estimated that 246,868 tons of BOD were produced

30 from Bali's economic activity in 2007. Further, we identified the chief BOD-emitting sectors and

31 found that intermediate demand and household demand were the major causes of BOD discharge

32 in the economy. Utilizing supply chain relationships, we also accounted for the indirect role of

33 each sector in total BOD emissions. Moreover, we categorized the sectors into four groups based

34 on their direct and indirect BOD emission characteristics and offered appropriate policy

35 measures for each group. Managing demand (i.e., lowering household consumption and exports)

36 and shifting input suppliers (i.e., from polluters to non-polluters) are effective measures to

37 control pollution for Categories I and II, respectively; clean production and abatement is advised 
38 for Category III; and a hybrid approach (i.e., demand management and abatement technology) is

39 recommended for Category IV.

40 Keywords: Biochemical oxygen demand (BOD), Bali, Environmentally extended input-output

41 (EEIO) modeling, Direct pollution, Water policy, Water pollution

\section{1. Introduction}

43 Global water resources are under immense pressure owing to increases in water demand that 44 are due to population growth and expanded industrial and economic activity. The stress has been

45 further exacerbated by increasing water pollution [1, 2]. Flörke et al. [3] reported that the global 46 withdrawal of domestic and industrial water increased by $77.7 \%$ with $300-1,345$ cubic 47 kilometers $\left(\mathrm{k}^{3}\right)$ withdrawn over the last six decades (1950-2010); of the extracted water, 88\% 48 was ultimately returned to the system as wastewater with limited treatment. The situation is a 49 serious concern in the Asia-Pacific region, which is undergoing rapid economic growth. 50 Consequently, the region's natural environment is being distressed by the consumption of huge 51 amounts of water, the release of waste and wastewater, and the expansion of pollution-prone 52 industries [4].

53 Bali, Indonesia, a famous global tourist destination in the Asia-Pacific region [5, 6], has 54 undergone rapid economic growth over the last three decades [7]. The Balinese economy is 55 traditionally supported by agriculture; however, it has recently become dominated by the tourism 56 sector [8]. In 2018, tourism (i.e., accommodation and food services) accounted for $23.34 \%$ of 57 Bali's gross regional domestic product (GRDP), while agriculture, forestry, and fisheries 58 accounted for $13.81 \%$ of its GRDP [6]. Bali's population was reported to be 4,380,800 as of 592020 with an average annual growth rate of $1.24 \%$ (2010-2018) [6, 9]. Rapid economic growth, 60 population growth, and poor water management will likely cause more serious water shortages in 
61 the future [10]. Despite its substantial potential for natural renewable water, Bali's water supply

62 is compromised because of an elongated coastland, lower groundwater potential, and a high

63 population density (FAO 2003 as cited in Strauß et al. [5]). By 2025, water consumption is

64 projected to expand by $70 \%[5,11]$. Water shortages are reported to reduce food production and

65 employment on the island, while both tourism and agriculture rely on an adequate water supply

$66[11,12]$.

67 Environmental degradation and pollution have put Bali's water resources at significant risk

$68[10,11]$. Water quality has been affected by recent economic development. For example, there is

69 a strong relationship between the existence of water pollutants, such as organic substances

70 (biochemical oxygen demand (BOD)) and fecal matter (Escherichia coli), in river water and

71 population density. Similarly, built-up areas, which have been increasing recently, have impacted

72 the river water quality negatively by elevating heavy metals (i.e., nickel and lead) and turbidity

73 [13]. Suteja et al. [14] reported that the two major rivers-namely, the Badung and Mati

74 Rivers - were the primary source of chromium deposits in the river estuary of Benoa Bay. A

75 significant amount of water pollutants is reportedly discharged in water bodies because of

76 intensive agricultural practices, including the excessive use of fertilizers and plant protection

77 chemicals [15]. Nitrate and phosphate contamination prevails in all the rivers, although the

78 contamination levels vary depending on the river and season. The highest loadings of nitrates

79 and phosphates were reported as 4.387 and 6.980 tons per day, respectively, in the Mati River,

80 which drains into Benoa Bay, in the dry season, thereby causing the water quality to exceed the

81 standard for marine biota [16, 17]. River water, namely, that of the Ayung and Badung Rivers, is

82 the major source of drinking water and irrigation. Meeting water quality standards, such as

83 having a BOD of 2 and 12 milligrams $(\mathrm{mg}) /$ liter (L), respectively, for class I (i.e., potable water 
84 supply) and class IV (i.e., irrigation use), as stipulated in the water quality management and

85 control measures of the Indonesian Government Regulations number 82 of 2001 [18], is 86 challenging.

87 The island of Bali operates two centralized wastewater treatment plants with a total capacity 88 of $61,000(51,000+10,000)$ cubic meters $\left(\mathrm{m}^{3}\right)$ per day $[10,15]$ as well as some community89 based decentralized wastewater treatment systems with limited capacities [19]. Since the current 90 treatment capacity is less than $10 \%$ of the total urban wastewater production $\left(642,000 \mathrm{~m}^{3} / \mathrm{day}\right.$, as 91 estimated in 2012) [10], a vast portion of wastewater from households, industries, hotels, 92 restaurants, business, and complexes, and waste and runoff of agriculture and livestock directly 93 drains into nearby canals, rivers, and ocean $[11,15,17]$. The direct discharge of toxic industrial 94 wastes into the river system that ultimately reaches the beaches has drawn significant attention $95[14,17]$. Several initiatives have been undertaken by government and private organizations; 96 nevertheless, these have not been enough to yield significant outcomes. Most studies have 97 focused on determining the water quality state, links with changes in land use, and particular 98 sectoral or sub-sectoral activities (e.g., textile industries and hotel businesses) [14-16, 20]. 99 However, the environmental performance of an economy is governed by all sectors, which are 100 interrelated through supply chains. Analyzing the relationship between economic activity and 101 water pollution is increasingly considered a useful approach to managing water resources [21, 102 22].

103 Generally, the pollution caused by economic activity is positively related to output [23]. The 104 economy of a country or region comprises several sectors, each of which receives inputs from its 105 own and other sectors by delivering outputs. Analyzing the inter-sectoral relationships along 106 with resource use (inputs) and pollutant emissions allows us to calculate resource use (e.g., 
107 energy, water, and land) and manage the environment (e.g., waste) [24]. Such an analysis

108 identifies sectors as either pollution sellers, buyers, or both, which is essential for prioritizing

109 pollution control policy [25]. To apply this approach, the conventional input-output (I-O) table

110 is extended to include environmental parameters (e.g., water pollutant emission intensity), which

111 are useful in evaluating the impact of production process (i.e., in the present or the future with

112 changes in the economy) on the water environment [21, 26-28].

113 In this study, we employed the environmentally extended input-output (EEIO) model to tie

114 water pollution together with Bali's economic activity. Broadly, our objective is to recommend

115 policies for managing Bali's water pollution in context of its rising economy. The specific

116 research objectives are to analyze the links between various economic activities and BOD

117 emissions, estimate direct and indirect sectoral BOD emissions, classify sectors into

118 comprehensive groups based on their BOD emission characteristics, and provide pollution

119 control management strategies.

$120 \quad$ 2. Study area

121 Bali, a province of Indonesia (Fig. 1), covers a total area of 5,620 square kilometers $\left(\mathrm{km}^{2}\right)$, or

$1220.30 \%$ of the total land area of the Indonesian archipelago. The island lies entirely within the

123 tropics and possesses a tropical marine climate. The average annual precipitation is

124 approximately 17,411 millimeters (mm) [6]. Rivers, groundwater, and springs-the major

125 freshwater resources - are not uniformly distributed across the region. Owing to the incidence of 126 major rainfall (75\%-80\%) during November through April, maintaining an adequate water

127 supply for the agriculture and tourism sectors is a challenge during the dry season [29].

128

Fig. 1 Map depicting the location of Bali Province 
129 In 2018, the Balinese economy reportedly grew by $6.35 \%$. The contribution of various

130 sectors to the GRDP for 2018 is demonstrated in Fig. 2 [6]. The accommodation and food service

131 sector's activities under tourism provide the dominant share of GRDP, followed by the

132 agricultural, forestry, and fishery sector. The contribution of the agricultural, forestry, and

133 fishery sector has declined in recent years. The Balinese economy has shifted from a primary to a

134 tertiary economy with the recent growth of the tourism sector [6]. Other sectors, such as the

135 transportation and construction industries, have a dominant share of the GRDP, accounting for

$1369.5 \%$ and $9.4 \%$, respectively. These sectors have reported increasing growth in the GRDP owing

137 to the expansion of the tourism sector. In total, 382 companies representing large (100 or more

138 employees) and medium (20-99 employees) industries were in operation in Bali in 2017; of

139 these, the food and beverage industry had the greatest share of the GRDP [6].

140 Fig. 2 Sectoral distribution of the gross regional domestic product (GRDP) of Bali, 2018

\section{3. Materials and methods}

142 3.1. Conventional I-O table

143 In an economy's production process, each sector requires inputs from its own and other

144 sectors to produce goods and services. The concept of describing the inter-linkages between

145 sectors in an economic system was introduced by the economist Wassily Leontief. His I-O

146 model is conventionally used to describe the interconnections between sectors [30]. Table 1

147 presents an example of an economy's flow of goods and services, visualizing the

148 interdependence between the sectors [31]. The rows represent the proportion of output that each

149 sector sells (seller) to other sectors (purchaser); the columns represent the proportion of products

150 and services required (purchased) by each sector from other sectors as inputs to meet total output.

151 Apart from intermediate demand, an $\mathrm{I}-\mathrm{O}$ table indicates the quantity of products and services 
152 consumed by households, the government, and exports (final demand) as well as the amount of

153 products and services that sectors import (imports) and the compensation paid to labor (value

154 added). I-O tables are formulated based on the data for a particular economic area, nation, or

155 region [32].

Table 1 Schematic representation of a conventional I-O table.

157 An I-O table comprises a set of linear equations. The basic equation of Leontief's model 158 describes the inter-sectoral relationships in an economic system [33]. It depicts the fact that total 159 output is equal to the amount used internally used by the system as intermediate consumption 160 plus the amount consumed by the final customers (Leontief as cited in Nguyen [21]).

$$
x_{i}=\sum_{j=1}^{n} x_{i j}+d_{i}
$$

161 where $x_{i j}$ is intermediate consumption [21], $d_{i}$ is the final demand for goods by each sector, and $162 a_{i j}$ is the technical coefficients of production, which are described as the amount of products that 163 the $j^{t h}$ sector purchases from the $i^{\text {th }}$ sector to produce one unit of $\left(j^{t h}\right)$ output.

$$
a_{i j}=\frac{x_{i j}}{x_{j}}
$$

164 Eq. (1) can be rewritten as follows after incorporating $a_{i j}$ :

$$
x_{i}=\sum_{j=1}^{n} a_{i j} x_{j}+d_{i}
$$

165 Converting the equation into matrix notation for the entire economy yields the following:

$$
x=A x+d
$$

$166 A$ represents the $n \times n$ technical coefficient matrix with the element (Table 1).

167 Solving for $x$, we obtain the total production delivered to fulfill final demand as follows: 


$$
x=(I-A)^{-1} d
$$

168 where $\boldsymbol{I}$ denotes an identity matrix and $(\boldsymbol{I}-\boldsymbol{A})^{-1}$ is the Leontief inverse matrix. Let $\alpha_{i j}$ represent

169 the elements of the Leontief matrix. Subsequently, the gross domestic output of sector $i, x_{i}$, can 170 be expressed as follows:

$$
x_{i}=\sum_{j=1}^{n} \alpha_{i j} d_{i}
$$

171 3.2. EEIO model

172 I-O tables show the flows between sectors and frame their interrelationships. An EEIO 173 analysis, an extension of Leontief's I-O model [32], is a simple and robust method for assessing

174 the links between economic activity and environmental impact [34]. EEIO quantifies the 175 environmental pressure along the supply chain while assuming an unchanged production 176 structure [35].

177 The release of water pollutants is usually expected to be linearly proportional to the size of 178 sectoral outputs $[21,23]$. We assume PI as pollution intensity and define it as the amount of 179 water pollutants released to produce one unit of output (in monetary terms) for a sector. Its 180 elements, $P I_{i}^{y}$, denote pollution intensity related to the $y^{\text {th }}$ water quality parameter for sector $i$ in

181 a particular year. The $y \times n$ matrix, PI, is the pollution intensity matrix. The pollution load (PL)

182 can then be computed using Eq. (7).

$$
P L=P I x
$$

183 The PL for the $k^{\text {th }}$ parameter for sector $i, P L_{i}^{k}$, is expressed as follows:

$$
P L_{i}^{y}=P I_{i}^{y} x_{i}
$$

184 Substituting the value of $x_{i}$ from Eq. (6) into Eq. (8) yields the following:

$$
P L_{i}^{k}=P I_{i}^{y} \sum_{j} \alpha_{i j} d_{i}
$$


185 The PL of sector $i$ is the amount released to satisfy all production in this sector $\left(x_{i}\right)$, including

186 both the intermediate $\left(\sum_{j} a_{i j} x_{j}\right)$ and final demand $\left(d_{i}\right)$.

187 3.3. Water pollutant emissions

188 Each economic sector acts as both a supplier and receiver of inputs in the economy's 189 production process. Based on their roles, the emissions of water pollutants from sectoral 190 activities can be distinguished into two categories: direct (i.e., a source of emissions) and indirect

191 (i.e., a cause of emissions). Direct emissions $(D i E)$ are defined as the amount of water pollutants

192 that are directly discharged by a sector in producing the products required to satisfy all forms of 193 demand (i.e., intermediate demand and final demand) [22]. By contrast, indirect emissions

$194(I D i E)$ are the amount of water pollutants that are discharged by a sector and other sectors to 195 produce the inputs it requires. Unlike direct emissions, the amount of pollutants indirectly 196 emitted by a sector relies heavily on the economic performance of several sectors. This form of 197 pollution is not accounted for by the traditional method; however, pollution control management 198 strategies have recently started incorporating examinations of indirect emissions [22, 36].

199 Despite being good indicators, direct and indirect emissions still cannot express the flow of 200 pollutants within a single sector $[21,22,30]$. These indicators cannot, for example, quantify the 201 proportion of a sector's direct discharge that is required to meet its own sectoral demand (i.e., 202 sectoral self-pollution) or the level of discharge equal to inter-sectoral demand.

203 We employed the vertical integrated coefficient method in sectoral pollutant flow analysis 204 [30] and disaggregated the sectoral PLs into five components: (i) a sector's own pollution $\left(O W_{i}^{y}\right)$ 205 (the amount of $y$ pollutant emitted by sector $i$ to produce its own input); (ii) true forward 206 pollution $\left(T F_{i}^{y}\right.$ ) (the amount of $y$ pollutant emitted by sector $i$ to produce products used as inputs 207 of others' intermediate demand); (iii) semi-own pollution $\left(S O W_{i}^{y}\right)$ (the amount of $y$ pollutant 
208 generated by sector $i$ to produce the inputs for other sectors, which is required to produce inputs

209 that sector $i$ purchases to fulfill final demand); (iv) true backward pollution $\left(T B_{i}^{y}\right.$ ) (the amount of

$210 y$ pollutant emitted by other sectors to provide inputs for a sector); and (v) final demand pollution

$211\left(F D_{i}^{y}\right)$; (the amount of $y$ pollutant directly emitted by sector $i$ to produce products in fulfilling the

212 final demand of a sector).

\section{3.4. Data sources and EEIO preparation}

214 Two datasets, namely, an I-O table and the sectoral water pollutant emission intensity, are

215 required to perform EEIO modeling. We used a 2007 regional $\mathrm{I}-\mathrm{O}$ table that originally consisted

216 of 52 economic sectors. The I-O table was revised by removing the sectors that lacked relevant

217 data (such as mining, basic metal industry, and other metal goods industries) and merging the

218 detailed economic sub-sectors into a major sector (e.g., agriculture, fishery, and forestry). Finally,

219 we developed a $16 \times 16$ sector $\mathrm{I}-\mathrm{O}$ table to provide comprehensive results and overcome the

220 limitation of lacking detailed pollutant emission intensities at the sub-sectoral level. The revised

221 grouping of sectors is provided in Supplementary A.

222 The revised $\mathrm{I}-\mathrm{O}$ table was further extended by adding the BOD emission intensity for each

223 economic activity as a proxy indicator of overall water quality [37, 38]. The intensity was

224 defined as the amount of BOD discharged per unit of monetary output in millions of rupiah

225 (IDR). The intensities were directly and indirectly collected/derived from various sources. The

226 intensity for the manufacturing sector was obtained from a report on wastewater disposal for

227 Denpasar [39]. The intensities were adjusted into 2007 prices (I-O table); price inflation was

228 overcome through the consumer price index method [40]. We derived the intensities for the

229 selected sectors by calculating the BOD load in kilograms $(\mathrm{kg})$ and taking its monetary output

230 value in 2007. The pollutant load for Sector 1 (agriculture, forestry, and fishery) was derived 
231 from the areas under each sub-sector [41] and the BOD export coefficients for major land use

232 [42-44]. Similarly, the BOD load for Sector 2 (livestock and poultry) was calculated by taking

233 daily livestock's load (BOD kg/day/cattle) [38] and slaughtering activities (kg/tons of meat) [45]

234 together with Bali's total number of cattle head and amount of meat produced in 2007 [41]. For

235 hotels and restaurants, we took the total number of visitors and restaurant seats in 2007 [41] and

236 calculated the BOD load per capita (visitor) per day and per restaurant seat [39]. In relation to the

237 service sectors - namely, electricity and drinking water, trading, transport, communication, and

238 financial institutions - that were not direct BOD emitters [36], the intensities from Nguyen et al.

239 [21] were used to examine their role in indirect BOD emissions.

240 Table 2 presents the EEIO table developed for Bali. Sectoral outputs are expressed in

241 millions of IDR; BOD emission intensity is expressed as $\mathrm{kg}$ per millions of IDR.

Table 2 Extended I-O table.

\section{4. Results and discussion}

\section{4.1. Sources of and causes for BOD emissions}

245 An estimated total of 246,868 tons of BOD was released in the economy's production

246 process in 2007. Each sectoral direct BOD load is shown in Fig. 3. Three sectors-livestock and

247 poultry (Sector 2); agriculture, forestry, and fishery (Sector 1); and food, beverage, coffee, and

248 tobacco (Sector 4)-accounted for $99.5 \%$ of the total BOD emissions; of these, Sector 2

249 produced $96 \%$ of the total BOD emissions. The BOD amount varied among the sectors because

250 of differences in BOD emission intensity and total output. The results are consistent with earlier

251 findings that indicated livestock plays a major role in freshwater pollution in many parts of the

252 world $[38,44,46]$. The increasing population and the prevalence of many head of cattle-the

253 reported increase in cattle and pig numbers was 3.62\% and $11.73 \%$, respectively, from 2017 to 
2542018 [6] - positioned this sector at the top in terms of water pollution. Conversely, the 255 agricultural land under Sector 1 has recently been declining; however, the heavy use of fertilizers 256 in intensive agricultural farming has kept the sector a leading cause of freshwater pollution. 257 Followed by these two sectors, Sector 4 (food, beverage, coffee, and tobacco) emitted BOD to a 258 greater extent, with a value of 1,894 tons, which notably serves to meet household consumption.

259 The remaining 13 sectors discharged 1,049 tons of BOD, which accounted for only $0.5 \%$ of the 260 total BOD emissions.

Fig. 3 Sectoral direct BOD discharge of BOD in the Balinese economy, 2007 (in tons)

The release of water pollutants increases with sectoral output, which is determined by a sector's intermediate and final demand. Intermediate demand reflects how heavily a sector 264 engages in supplying its products to other sectors as inputs. Household consumption, government 265 stock, and exports of a sectoral item determine a sector's final demand. Disaggregating the total 266 PL as per the demand for each sector (Fig. 4) is an effective method of undertaking the 267 appropriate policy measure in controlling water pollution. This figure illustrates that demand 268 factors impact the BOD emissions differently for the various sectors. For instance, intermediate 269 demand was the major cause of BOD emissions in four major sectors, including the top two 270 BOD emitters (Sectors $1-3$ and 12). This indicates that these sectors discharged major BOD in 271 producing their products or services for other economic sectors. However, exports were the 272 major cause of BOD emissions (more than 60\% of BOD) in the sectors (Sectors 5-9 and 13) that 273 mainly comprise manufacturing industries. This is likely attributable to Bali's adoption of an 274 open economy as exports play an important role in the regional economy [6]. Household demand 275 was the primary cause of BOD (nearly 50\%) for Sector 4 (food, beverage, coffee, and tobacco) 276 and Sector 10 (electricity and drinking water), which are both heavily consumed by residents. 
277 Gross stock and changes had negative BOD values for Sectors 4 and 5, indicating that this 278 portion (BOD) was not generated for that year but fulfilled by the stock.

279 Fig. 4 Percentage of total BOD discharge attributable to each component of each sector's total output

281 Apart from the direct BOD discharge, we determined indirect BOD emissions by sector (Fig.

282 5). Sectors 2, 13, 1, and 4 produced as much BOD from other sectors or from themselves to 283 satisfy their inputs. Sector 2 was the chief indirect BOD emitter, accounting for $65 \%$ of total 284 BOD emissions; this is likely due to its reliance on its own sector, which is the top direct BOD 285 emitter, for inputs (e.g., baby chicks, calves, fingerlings, and animal feeds). Sector 13 (hotels and 286 restaurants) is responsible for emitting $30 \%$ of total BOD owing to its close connection with 287 other sectors - most likely the livestock and agricultural sectors, both major BOD emitters- to 288 operate their business. Importantly, other service and trade sectors show a noticeable 289 contribution to indirect BOD emissions as opposed to their role in direct BOD emissions. This is 290 particularly essential for pollution control planning because the direct emissions of these sectors 291 are often overlooked.

292 Fig. 5 Indirect BOD discharged relative to total BOD discharge in the Balinese economy,

\section{4.2. Disaggregation of sectoral BOD emissions}

295 An analysis of the sectoral roles in indirect water pollutant emissions has added a new 296 perspective to the conventional approach of direct sectoral water pollution. However, although 297 these are good indicators, these aspects (i.e., direct and indirect pollution) remain unable to fully 298 depict the behavior of sectoral pollution in the economy. To enrich our analysis, we demonstrate 299 the flow of BOD throughout the entire economic sector (Table 3) and its various pollution 
components (Table 4). In Table 3, the rows of the matrix indicate the BOD amount that sector $i$

301 produces to fulfill sector $j$ 's demand. The row sums represent the total BOD directly emitted by

302 sector $i$ in producing products or services to fulfill all forms of the economy's demand (i.e., DiE).

303 The columns of matrix $j$ indicate the purchases made by sector $j$ from sector $i$ during the

304 production process, and the column sums represent the total BOD indirectly emitted by sector $j$

305 from other sectors (i) in obtaining its input requirements (i.e., IDiE). The absence of row data for

306 Sectors 10, 14, and 15 indicates that these sectors do not directly emit BOD (row), while the

307 column values for the same sectors show their indirect role in producing BOD in the economy.

308 Subsequently, we disaggregate sectoral BOD loads into five components: (i) a sector's own

309 pollution $\left(O W_{i}^{y}\right)$ (the amount of $y$ pollutant emitted by sector $i$ to produce its own input); (ii)

310 semi-own pollution $\left(S O W_{i}^{y}\right)$ (the amount of $y$ pollutant generated by sector $i$ to produce the

311 inputs for other sectors, which is required to produce inputs that sector $i$ purchases to fulfill final

312 demand); (iii) true forward pollution $\left(T F_{i}^{y}\right.$ ) (the amount of $y$ pollutant emitted by sector $i$ to

313 produce products used as inputs in others' intermediate demand); (iv) true backward pollution

$314\left(T B_{i}^{y}\right)$ (the amount of $y$ pollutant emitted by other sectors to provide inputs for a sector); and (v)

315 final demand pollution $\left(F D_{i}^{y}\right)$; (the amount of $y$ pollutant directly emitted by sector $i$ to produce

316 products in fulfilling the final demand of a sector) (Table 4).

317 The values vary among the sectors according to their different emission properties. For

318 instance, a high value of $T F_{i}^{y}$ for Sectors 1 and 2, pollution seller sectors, indicates that these

319 sectors produce considerable BOD in satisfying intermediate demand. Similarly, Sector 2 is also

320 responsible for producing substantial BOD (24.7\% of the total BOD) in fulfilling its own inputs,

321 highlighting the internal dependence of the sector (for their own inputs, i.e., $O W_{i}^{y}$ ). Other than

322 Sectors 1,2 , and 3, a majority of sectors have a typically high range of $T B_{i}^{y}$, characterizing these 
323 sectors as pollution inducers that cause other sectors to emit BOD to fulfill their input needs.

324 Among these, Sector 13 (hotels and restaurants) has an exceptionally high value, indicating a 325 close linkage between this sector and others and its responsibility for producing a significant 326 amount of the economy's water pollutants. Sector 4 (food, beverage, coffee, and tobacco) is a 327 major pollution inducer because of its processing of raw primary products (i.e., agricultural and 328 livestock products) into edible food items.

Table 3 Matrix of BOD $(\mathrm{kg})$ flow in the economy.

\subsection{Grouping of sectors}

332 To distinguish the sectoral BOD emission behavior and appropriately identify the 333 management plan, we grouped sectors by plotting the percentage of BOD - true forward 334 pollution $\left(T F_{i}^{y}\right) /$ direct emissions $(D i E)$ and true backward pollution $\left(T B_{i}^{y}\right) /$ indirect emissions 335 (IDiE) (Fig. 6). DiE is defined as the amount of water pollutants (herein BOD) that are directly 336 discharged by a sector while producing the products required to satisfy all forms of demand (i.e., 337 intermediate demand and final demand) [22]. By contrast, IDiE is the amount of water pollutants 338 (herein BOD) that are discharged by a sector and other sectors to produce the inputs that it 339 requires. Generally, high $T F_{i}^{y} / D i E$ values indicate that the sectors are liable to produce more 340 water pollutants for other sectors, so the proportion of water pollutants produced for their own

341 sectoral inputs is lower. Conversely, sectors with high $T B_{i}^{y} / I D i E$ produce more water pollutants 342 from other sectors.

343 Figure 6 shows that most sectors fall under Categories I and II. In contrast, there is only one 344 sector in Category III, and none of the sectors belong to Category IV. Category I has less than $34550 \%$ of both $T F_{i}^{y} / D i E$ and $T B_{i}^{y} / I D i E$, indicating that the sectors depend heavily on their own 
sectoral input and produce more than $50 \%$ of the total direct and indirect sectoral BOD discharge

347 in fulfilling their own sector's input demands. As major sources of pollution for their own input

348 requirements, these sectors are characterized as self-polluting sectors. The pollution under this

349 category could be better addressed by the product's final demand. In this regard, policy should

350 focus on measures to lower household consumption and reduce the exports of these sectors.

Fig. 6 Classification of sectors based on their BOD emissions characteristics

\section{3} Category II is similar to Category I in that $T F_{i}^{y} / D i E<50 \%$ but has a high $T B_{i}^{y} / I D i E$ (i.e., more than 50\%). In addition, by producing a large amount of BOD in fulfilling their own input requirements, these sectors indirectly produce a higher amount of BOD (more than $50 \%$ of the total sectoral indirect BOD emissions) from other sectors. Apart from self-polluters, these sectors are characterized as pollution inducers. Sectors such as Sectors 14 and 15 lie to the right bottom because of the lack of their own direct BOD discharge ( $D i E$ is 0 ); however, these sectors indirectly cause a significant amount of BOD from other sectors. In terms of the pollution control perspective, there is a need to examine input suppliers (seller sector) under this category and possible measures for switching the supplier sector from high- to low-polluting suppliers.

A single sector (Sector 3, i.e., padas stone and other minerals) is found under Category III. This possesses a high (over $50 \%$ ) of $T F_{i}^{y} / D i E$ but has a $T B_{i}^{y} / I D i E$ value of less than $50 \%$, indicating that the sector emits considerable BOD to fulfill intermediate demand and that it does not cause other sectors to produce BOD for its input requirements. This category of sectoral pollution control will be better dealt with by implementing clean production technologies and wastewater treatment practices. No sectors can be found under Category IV, which is characterized by indirectly producing a huge amount of BOD from the other sectors and also directly producing a significant amount of BOD to supply other sector demand. Although we did 
not find any sectors in this group, two sectors (i.e., Sectors 10 and 12) were extremely close to

370 this category.

\section{5. Policy implications and perspectives for pollution control}

372 The analysis herein of sectoral water pollution behavior in the production process of the 373 economy offers vital policy directives for controlling water pollution. In this study, livestock and 374 poultry sectors were categorized as the chief BOD emitter; therefore, major attention should be 375 paid to this sector. The handling and treatment of livestock waste is not common despite such 376 waste containing valuable ingredients that can be processed for manure and biogas production. A 377 typical BORDA biodigester can be used to handle animal waste in parts of Indonesia with 378 satisfactory performance [18]. The optimization of biodigester performance and the expansion of

379 its use comprise an effective method to control animal waste-derived water pollution. In relation 380 to poultry waste, it is either composted or used for animal feedstuffs. Studies conducted globally 381 and locally (i.e., in Indonesia) have demonstrated the possibility of turning poultry waste into 382 valued feedstuffs for ruminants [47, 48]. Under the context of increased poultry waste, the policy 383 of recovering animal waste and turning it into a valuable product would be the best option.

384 Technical and financial issues in implementing related technologies should be supported by 385 offering incentives. The application of the technologies (i.e., the biodigester or drying poultry 386 manure for feedstuffs) would be more beneficial in terms of the technical and economic aspects 387 for large-scale farming; therefore, policy encouraging the development of large-scale livestock 388 and poultry farming should be prioritized. To minimize the pollutant loads from agriculture, 389 fertilizer usage, including doses, timing, and methods, should be considered. Cleaner production 390 and wastewater treatment practices should focus on the safe discharge of the wastewater 
391 produced, especially from manufacturing industries such as Sectors 4 (food, beverage, coffee, 392 and tobacco) and 8 (fuels and chemical industry, rubber, plastics).

393 Decreasing the total output of each sector by cutting its demand is the best method to control

394 water pollution. The total output consists of the intermediate and final demands of the economy, 395 while the final demand is further directed by exports, households, and gross stock. These 396 components of demand should be carefully examined and considered in terms of pollution 397 reduction. For instance, exports are responsible for producing a significant amount of BOD from 398 major manufacturing industries such as Sectors 5 (textile, apparel, and leather goods), 6 (timber 399 industry and wood products), 7 (paper industry, paper, and cardboard goods), 8 (fuels and 400 chemical industry, rubber, plastics), and 9 (other processing industries). Curtailing the exports of 401 these sectors based on their pollution loads to minimize the water pollution load could be an 402 alternative. However, such policies should be examined from an economic and social perspective. 403 Household consumption is the primary reason for BOD emissions by the top BOD emitters404 Sectors 4 (food, beverage, coffee, and tobacco) and 2 (livestock and poultry). Changes in 405 household consumption, including changes in dietary habits (e.g., shifting consumable food 406 items toward environmentally friendly products), could be the best approach to minimize the PLs 407 from these sectors. Although such changes may take time, starting initiatives in this area would 408 significantly impact pollution control in the long term. Considering indirect roles, Sector 13 409 (hotels and restaurants) demonstrates significant impact on water pollution by indirectly inducing 410 BOD. The indirect BOD discharge of Sector 13 is around 190 times higher than the sector's 411 direct BOD emissions. This sends an important message - aside from focusing on pollution 412 control practices within the premises of hotels and restaurants, policy should also seek and 413 prioritize supply-side pollution (from associated sectors). This provides new insights, such as 
414 offsetting the high investment cost for Sector 2 to adopt a wastewater treatment plant, by

415 mobilizing the environmental fees/revenue collected from another sector, for example, the

416 tourism sector. Alternatively, the possibility of decreasing the livestock and poultry population

417 and increasing the imports of such products could be sought. Again, socioeconomic aspects

418 should be evaluated for such decision-making

419 The classification of the sectors (Fig. 6) serves as a useful tool in planning appropriate 420 pollution control policies. Managing demand by lowering household consumption, changing

421 food habits (toward environmentally friendly food), and curtailing exports are effective methods

422 to inhibit the water pollution of the sectors in Category I. Sectors under Category II are subject to 423 pollution control by seeking alternative input suppliers (from high- to low-polluting suppliers) 424 aside from the measures suggested for Category I. Sectors under Category III will be better 425 managed by implementing clean production technology and wastewater treatment practices.

\section{6. Conclusions}

427 This study is the first to analyze the relationship between economic activity and the potential 428 for water pollution in Bali, Indonesia. Going beyond conventional methods, potential water429 polluting sectors were identified in this study based on their direct and indirect roles in BOD 430 emissions. This study recognizes significant BOD emission drivers, guiding policymakers and 431 practitioners to target initiatives that reduce Bali's water pollution. Certain sectors-namely, 432 Sector 2 (livestock and poultry), Sector 1 (agriculture, forestry, and fishery), and Sector 4 (food 433 and beverage) - accounted for $99.5 \%$ of the direct BOD discharge, among which Sector 2 434 accounted for $96 \%$ of the total BOD discharged. For direct BOD emissions, intermediate demand 435 was a major driver in Sectors 1-3 and Sector 12. Similarly, exports were the cause of more than $43660 \%$ of total BOD emissions for the manufacturing sectors (Sectors 5-9 and 13). Household 
437 demand dominated the major portion of BOD emissions in Sectors 4 (food, beverage, coffee, and 438 tobacco) and 10 (electricity, and drinking water).

439 In particular, we determined each sector's indirect BOD emissions. The livestock and poultry 440 sector, the top BOD emitter, produced more than $50 \%$ of its BOD for its own sector demand,

441 which was also recognized as the most self-polluting sector. Hotels and restaurants heavily rely

442 on other sectors and were responsible for indirectly emitting BOD from different sectors. Sectors

443 such as the trades, transportation, and service sectors, whose direct BOD emissions are limited,

444 still significantly contributed to indirect BOD emissions.

445 Moreover, we grouped the sectors into four categories. Those in Category I emit considerable 446 water pollutants for their own input requirements; these sectors are called self-polluters and are

447 better addressed by demand management and employing clean production technologies. Sectors 448 in Category II directly emit a significant portion of water pollutants for their own sector's input 449 demand but heavily rely upon the total indirect water pollutants from other sectors. This 450 category's pollution control will be better managed by shifting from high- to low-polluting 451 suppliers in addition to the measures employed in Category I. Category III emits water pollutants 452 to fulfill other (intermediate) sectoral demand; therefore, clean production technology and 453 wastewater treatment should be encouraged. No sectors fell under Category IV, which produces 454 and causes more water pollutants for and from other sectors, and for which a hybrid of the 455 measures suggested for Categories II and III should be employed.

\section{7. Limitations}

457 For this research, we used an available $2007 \mathrm{I}-\mathrm{O}$ table; however, using the latest $\mathrm{I}-\mathrm{O}$ data 458 would have enhanced our analysis. The $\mathrm{I}-\mathrm{O}$ table was extended by adding available BOD 
459 emissions intensities. Establishing sub-sectoral pollution intensities and adding new water

460 quality indicators could strengthen similar analyses in the future.

$461 \quad \underline{\text { Declarations }}$

462 Availability of data and materials

463 All data generated and analyzed during this study are available from the corresponding author

464 upon reasonable request.

465 Competing interests

466 The authors declare they have no competing interests.

467 Funding

468 This work was carried out as part of the United Nations University Institute for the Advanced

469 Study of Sustainability (UNU-IAS) project Water for Sustainable Development (WSD), which is

470 supported by the Ministry of Environment of Japan (MoEJ).

471 Authors' contributions

472 SKC contributed to the conceptualization, methodology, data interpretation, reviewing, and

473 writing - original draft preparation. GM contributed to the methodology and data interpretation.

474 ABR provided the data preparation and GIS map. CP processed the review and editing. IMS

475 provided the policy implications. KF provided the supervision and funding acquisition. All

476 authors read and approved the final manuscript.

477 Acknowledgments

478 The authors wish to thank the Ministry of Environment of Japan (MoEJ) for funding the project

479 and Badan Pusat Statistik Provinsi Bali (Statistics of Bali Province) for providing the necessary

480 data.

$481 \quad$ References 
482 1. Boretti A, Rosa L. Reassessing the projections of the World Water Development Report. NPJ

483 Clean Water. 2019;2:15. https://doi.org/10.1038/s41545-019-0039-9.

484 2. Kumar V, Parihar RD, Sharma A, Bakshi P, Singh Sidhu GP, Bali AS, et al. Global 485 evaluation of heavy metal content in surface water bodies: A meta-analysis using heavy 486 metal pollution indices and multivariate statistical analyses. Chemosphere. 2019;236:124364. $487 \quad$ https://doi.org/10.1016/j.chemosphere.2019.124364.

488 3. Flörke M, Kynast E, Bärlund I, Eisner S, Wimmer F, Alcamo J. Domestic and industrial 489 water uses of the past 60 years as a mirror of socio-economic development: A global simulation study. Glob Environ Change. 2013;23:144-56. https://doi.org/10.1016/j.gloenvcha.2012.10.018.

4. Asian Development Bank. Asian Water Development Outlook 2013: Measuring water security in Asia and the Pacific. Mandaluyong City, Philippines; 2013. https://www.adb.org/sites/default/files/publication/30190/asian-water-development-outlook2013.pdf. Accessed 13 February 2021.

5. Strauß S. Water conflicts among different user groups in South Bali, Indonesia. Hum Ecol. 2011; 39:69-79. https://doi.org/10.1007/s10745-011-9381-3.

\section{9.}

500 7. Huntsman AC, White NG. Modernization in Bali, Indonesia and the influence of socio501 economic factors on the nutritional status of preschool children in 1989/1990: An anthropometric study.

Ann

Hum

Biol.

2007;34:411-24. https://doi.org/10.1080/03014460701366373 
504 8. Siska ME, Sayama T, Takara K (2018a) Spatial and seasonal variabilities of water use and availability in Bali. J JSCE, Ser B1 74:I_1333-I_1338.

$506 \quad$ https://doi.org/10.2208/jscejhe.74.I_1333

9. BPS-Badan Pusat Statistik Provinsi Bali. Strategic indicators. 2021 https://bali.bps.go.id/QuickMap?id=0000000000. Accessed 2 Feb 2021.

10. ARCOWA. Wastewater management and resource recovery in Indonesia: current status and opportunities. 2018. http://seaknowledgebank.net/sites/default/files/wastewater_management_and_resource_reco very_in_Indonesia_1.pdf. Accessed 13 February 2021.

513 11. Rai IN, Shoba S, Shchegolkova N, Dzhamalov R, Venitsianov E, Santosa IGN, et al. 514 Analysis of the specifics of water resources management in regions with rapidly growing 515 population under different climate conditions: Case study of Bali Island and the Moscow 516 Region. Water Resour. 2015;42:735-46. https://doi.org/10.1134/S0097807815050127.

517 12. Cole S. A political ecology of water equity and tourism. Ann Tour Res. 2012;39:1221-41. $518 \quad$ https://doi.org/10.1016/j.annals.2012.01.003.

519 13. Rimba AB, Mohan G, Chapagain SK, Arumansawang A, Payus C, Fukushi K, et al. Impact 520 of population growth and land use and land cover (LULC) changes on water quality in 521 tourism-dependent economies using a geographically weighted regression approach. Environ 522 Sci Pollut Res. 2021. https://doi.org/10.1007/s11356-020-12285-8.

523 14. Suteja Y, Dirgayusa IGNP, Purwiyanto AIS. Chromium in Benoa Bay, Bali - Indonesia. Mar $524 \quad$ Pollut Bull. 2020;153:111017. https://doi.org/10.1016/j.marpolbul.2020.111017

525 15. Wayan Budiasa I, Gusti Ngurah Santosa I, Nyoman Sunarta I, Ketut Suada I, Nyoman Rai I, 526 Ratna Dewi AAI, et al. The Potential Use of Bali Wastewater for Crop Production Based on 
Moscow Region Experience. Water Resour. 2018;45:138-147.

$528 \quad$ https://doi.org/10.1134/S0097807818010074.

529 16. Suteja Y, Purwiyanto AIS. Nitrate and phosphate from rivers as mitigation of eutrophication

530 in Benoa bay, Bali-Indonesia. IOP Conf Ser: Earth Environ Sci. 2018;162:012021.

$531 \quad$ https://doi.org/10.1088/1755-1315/162/1/012021.

532 17. Lewis J, Lewis B. Bali's silent crisis: desire, tragedy, and transition. Lexington Books; 2008.

533 18. WEPA-Water Environment Partnership in Asia. Water standards of partner countries. 2017.

$534 \quad$ http://wepa-db.net/en/topic/waterstandard/index.html. Accessed 2 Mar 2021.

535 19. Rochmadi R, Ciptaraharja I, Setiadi T. Evaluation of the decentralized wastewater treatment

536 plants in four provinces in Indonesia. Water Pract Technol. 2010;5:4: wpt2010091. $537 \quad$ https://doi.org/10.2166/wpt.2010.091.

538 20. Pramono, J. The process of environmental management at star rated hotel in Bali. Tourism \& 539 sustainable regional development In Indonesia. 2016;20-32.

540 21. Nguyen HT, Aviso KB, Kojima N, Tokai A. Structural analysis of the interrelationship 541 between economic activities and water pollution in Vietnam in the period of 2000-2011.

542 Clean Techn Environ Policy. 2018;20:621-38. https://doi.org/10.1007/s10098-018-1492-8.

543 22. Hoang LE A, Tokai A, Yamamoto Y (2012) Structural analysis of relationship between 544 economic activities and water pollution in Vietnam. J. Japan Soc. Hydrol. and Water Resour. $545 \quad$ 2012;25:139-151. https://doi.org/10.3178/jjshwr.25.139.

546 23. Ang JB. Economic development, pollutant emissions and energy consumption in Malaysia. J

547 Policy Model. 2018;30:271-278. https://doi.org/10.1016/j.jpolmod.2007.04.010.

548 24. Duarte R, Yang H. Input-output and water: introduction to the special issue. Econ Syst Res.

$549 \quad$ 2011;23:341-51. https://doi.org/10.1080/09535314.2011.638277. 
25. Ali SH, Puppim de Oliveira JA. Pollution and economic development: an empirical research review. Environ Res Lett. 2018;13:123003. https://doi.org/10.1088/1748-9326/aaeea7.

552 26. Chapagain SK, Mohan G, Fukushi K. An extended input-output model to analyze links 553 between manufacturing and water pollution in Nepal. Water Air Soil Pollut. 2020;231:570. $554 \quad$ https://doi.org/10.1007/s11270-020-04940-0.

555 27. Resosudarmo BP. River water pollution in Indonesia: an input-output analysis. IJESD 2003;2:62. https://doi.org/10.1504/IJESD.2003.002363.

557 28. Sánchez-Chóliz J, Duarte R. Water pollution in the Spanish economy: analysis of sensitivity 558 to production and environmental constraints. Ecol Econ. 2005; 53:325-338. $559 \quad$ https://doi.org/10.1016/j.ecolecon.2004.09.013.

560 29. JICA- Japan International Cooperation Agency.The comprehensive study on water resources 561 development and management in Bali Province in the Republic of Indonesia final report. 5622006.

563 30. Sanchez-Choliz J, Duarte R. Analysing pollution by way of vertically integrated coefficients, 564 with an application to the water sector in Aragon. Cam J Econ. 2003; 27:433-448. $565 \quad$ https://doi.org/10.1093/cje/27.3.433.

566 31. Tanaka FJM. Applications of Leontief's input-output analysis in our economy. Faculty of 567 Economics Journal University of Nagasaki. 2011;45:1, 29-96.

568 32. Miller RE, Blair PD. Input-output analysis: Foundations and extensions (2nd ed). 569 Cambridge: Cambridge University Press; 2009.

570 33. Mohan G, Chapagain SK, Fukushi K, Papong S, Sudarma I. M, Rimba AB, et al. An 571 Extended Input-Output Framework for Evaluating Industrial Sectors and Provincial-Level 
Water Consumption in Indonesia. Water Resour Ind. 2021:100141.

$573 \quad$ https://doi.org/10.1016/j.wri.2021.100141.

574 34. Kitzes J. An Introduction to environmentally-extended input-output analysis. Resources.

575 2013;2:489-503. https://doi.org/10.3390/resources2040489.

576 35. Donati F, Aguilar-Hernandez GA, Sigüenza-Sánchez CP, de Koning A, Rodrigues JFD,

577 Tukker A. Modeling the circular economy in environmentally extended input-output tables:

578 Methods, software and case study. Resour Conserv Recycl. 2020;152:104508.

$579 \quad$ https://doi.org/10.1016/j.resconrec.2019.104508.

580 36. Chakraborty D, Mukhopadhyay K. Water Pollution and Abatement Policy in India. vol. 10.

581 Dordrecht: Springer Netherlands; 2014. https://doi.org/10.1007/978-94-017-8929-5.

582 37. Damania R, Desbureaux S, Rodella A-S, Russ J, Zaveri E. Quality Unknown: The Invisible

583 Water Crisis. Washington, DC: World Bank; 2019. https://doi.org/10.1596/978-1-4648-1459-

$584 \underline{4}$

585 38. Wen Y, Schoups G, van de Giesen N. Organic pollution of rivers: Combined threats of 586 urbanization, livestock farming and global climate change. Sci Rep. 2017; 7:43289. $587 \quad$ https://doi.org/10.1038/srep43289.

588 39. JICA- Japan International Cooperation Agency. The development study on wastewater 589 disposal for Denpasar. 1993.

590 40. Jha S, Mani M.Trade liberalization and the environment in Vietnam. Washington, D.C.: The 591 World Bank; 2006. https://doi.org/10.1596/1813-9450-3879.

592 41. BPS-Badan Pusat Statistik Provinsi Bali. Bali Province in Figures 2008, Denpasar, Bali; 5932008. 
594 42. Boyd CE. Effluent effects from aquaculture pond. In Global Aquaculture Alliance. 2006.

595 https://www.aquaculturealliance.org/advocate/effluent-effects-from-aquaculture-ponds/.

$596 \quad$ Accessed 30 Aug 2020.

597 43. Choi D-H, Beom J-A, Jeung M-H, Choi W-J, Her Y-G, Yoon K-S. Characteristics of 598 biochemical oxygen demand and chemical oxygen demand export from paddy fields during 599 rainfall and non-rainfall periods. Paddy Water Environ. 2019;17:165-75. $600 \quad$ https://doi.org/10.1007/s10333-019-00708-3.

601 44. Vigiak O, Grizzetti B, Udias-Moinelo A, Zanni M, Dorati C, Bouraoui F, et al. Predicting 602 biochemical oxygen demand in European freshwater bodies. Sci Total Environ. 603 2019;666:1089-1105. https://doi.org/10.1016/j.scitotenv.2019.02.252.

604 45. Verheijen LAHM, Wiersema D, Pol LH, De Wit J. Management of waste from animal 605 product processing. International Agriculture Center, Wageningen, The Netherlands; 1996.

606 46. Gu P, Shen RF, Chen YD. Diffusion pollution from livestock and poultry rearing in the 607 Yangtze Delta, China. Environ Sci Pollut Res. 2018;15:273-277. $608 \quad$ https://doi.org/10.1065/espr2007.07.438.

609 47. Adli DN, Sjofjan O, Mashudi M. Dried of Poultry Waste Urea-Molasses Block (dpw-umb) as 610 Potential for Feed Supplementation. J Agripet. 2017;17:144-149. $611 \quad$ https://doi.org/10.17969/agripet.v17i2.8391.

612 48. Ghaly AE, MacDonald KN. Drying of poultry manure for use as animal feed. Am J Agric 613 Biol Sci. 2012;7:239-254. https://doi.org/10.3844/ajabssp.2012.239.254. 


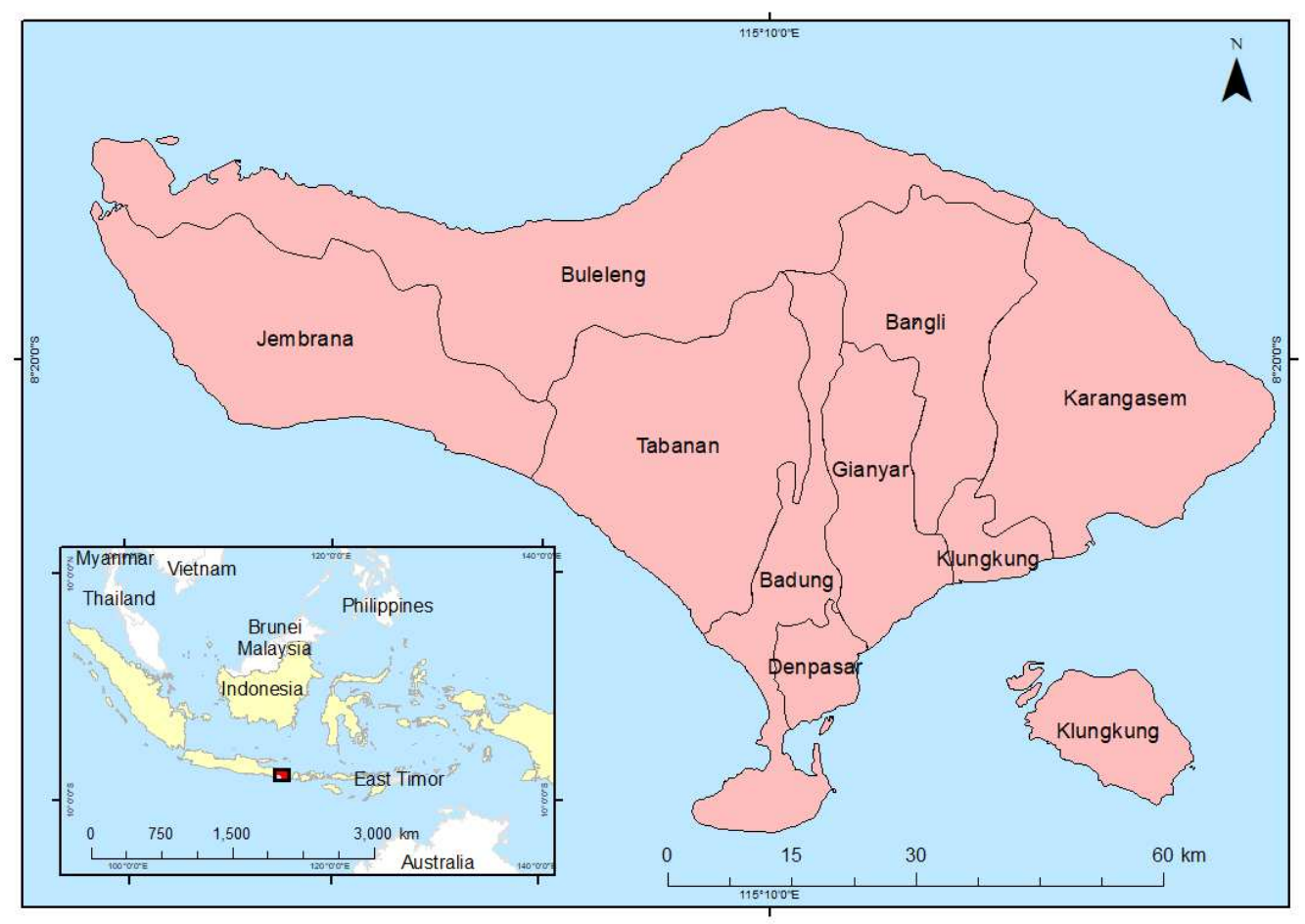

Fig. 1 Map depicting the location of Bali Province
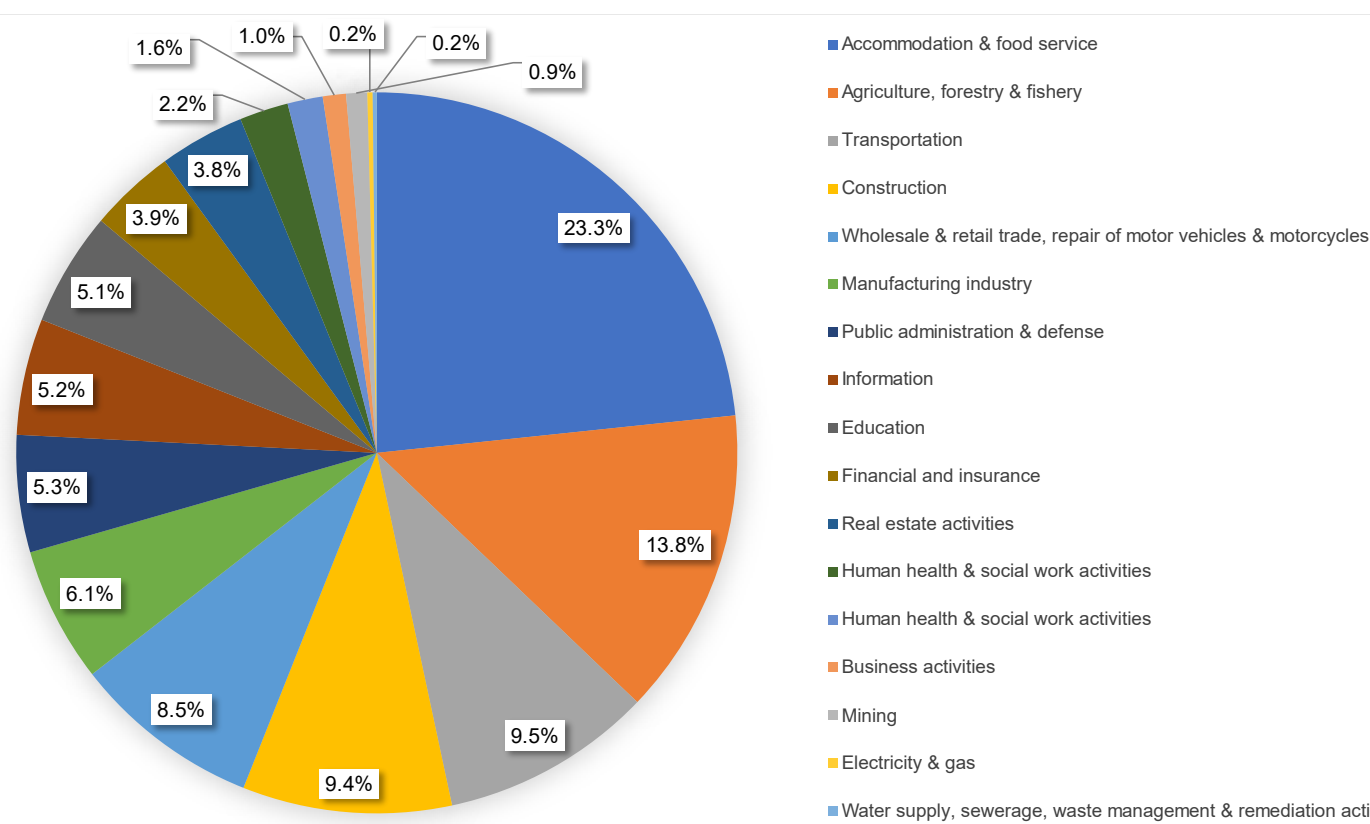

-Water supply, sewerage, waste management \& remediation activities

Fig. 2 Sectoral distribution of the gross regional domestic product (GRDP) of Bali, 2018 

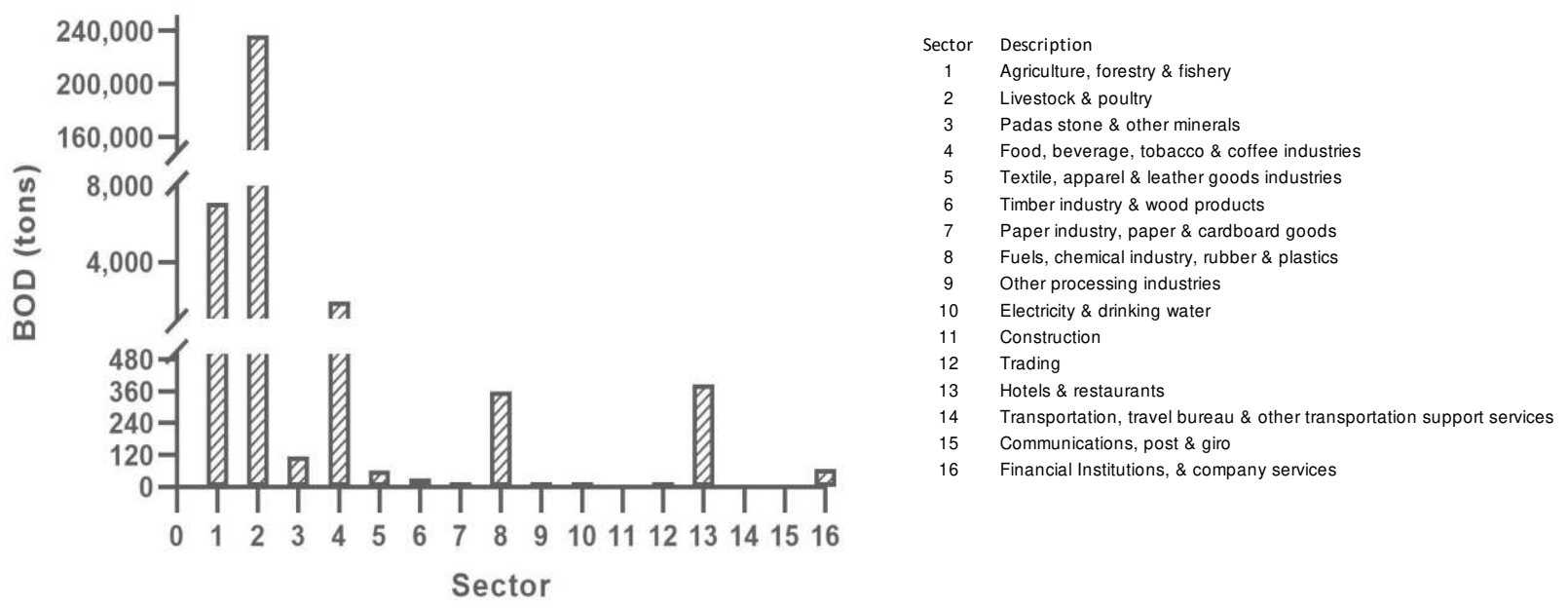

Fig. 3 Sectoral direct discharge of BOD in the Balinese economy, 2007 (in tons)

620

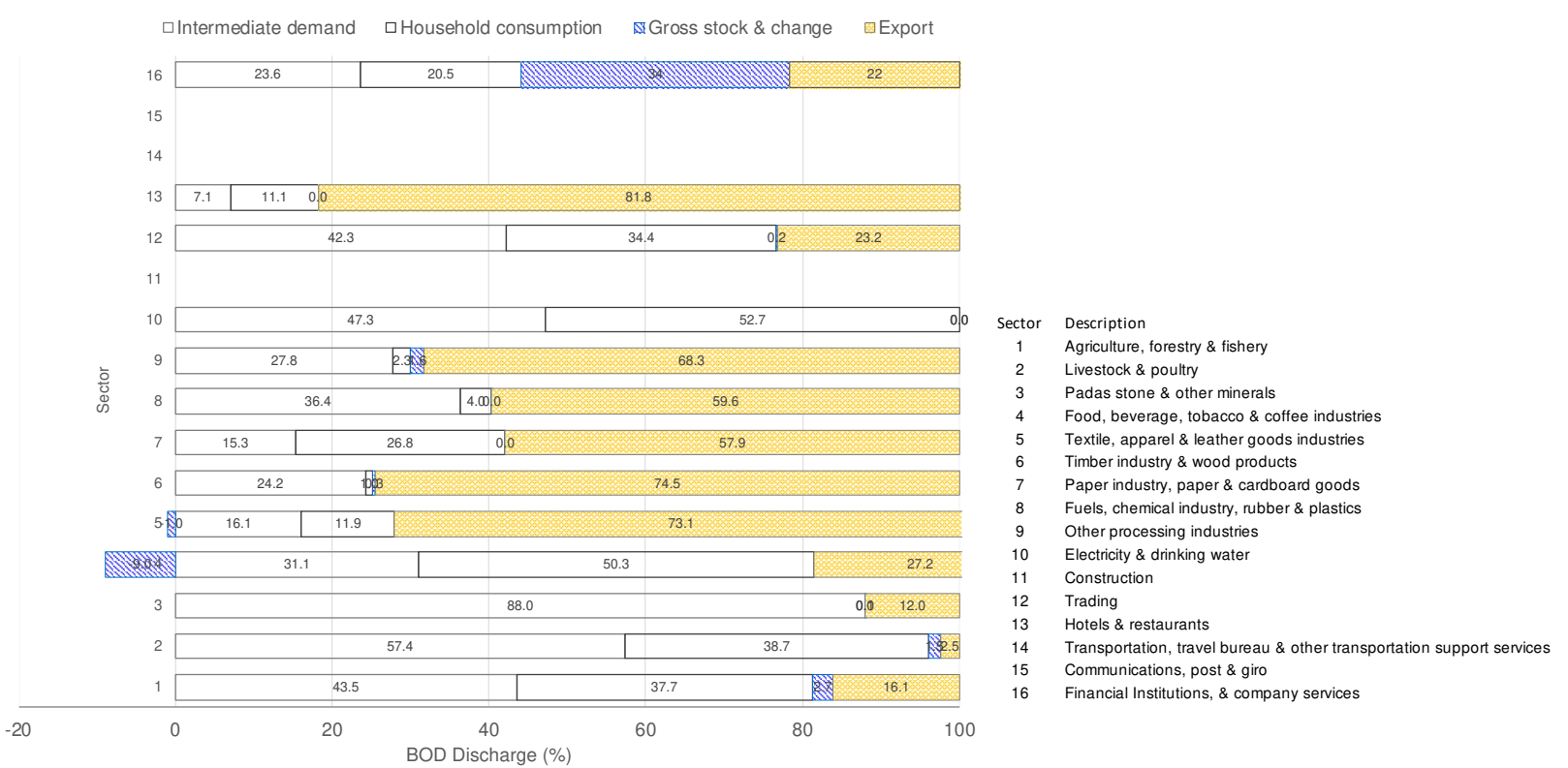

Fig. 4 Percentage of total BOD discharge attributable to each component of each sector's total output

Note: Sectors 11, 14, and 15 do not release significant BOD 


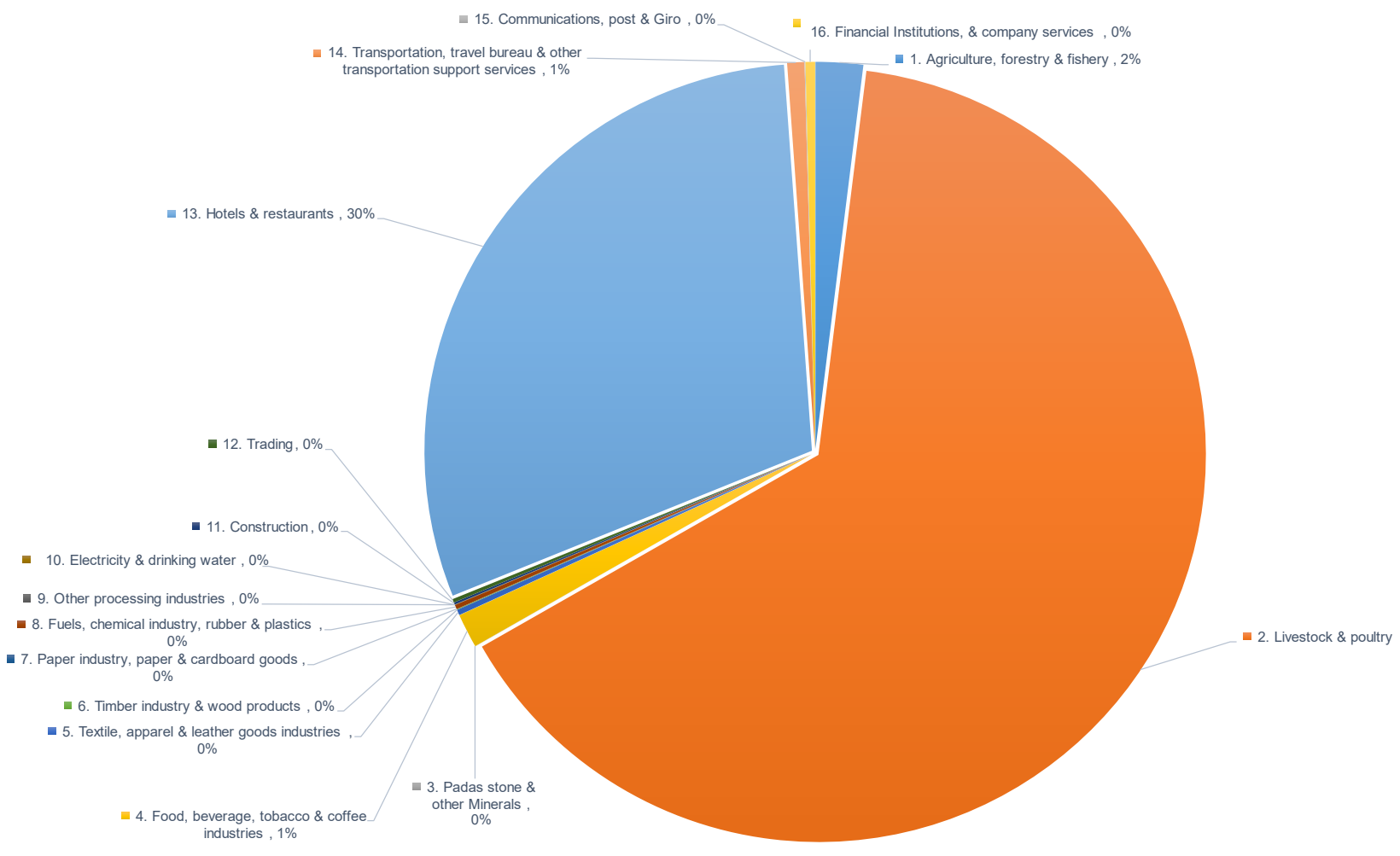

Fig. 5 Indirect BOD discharged by each sector relative to total BOD discharge in the Balinese economy, 2007

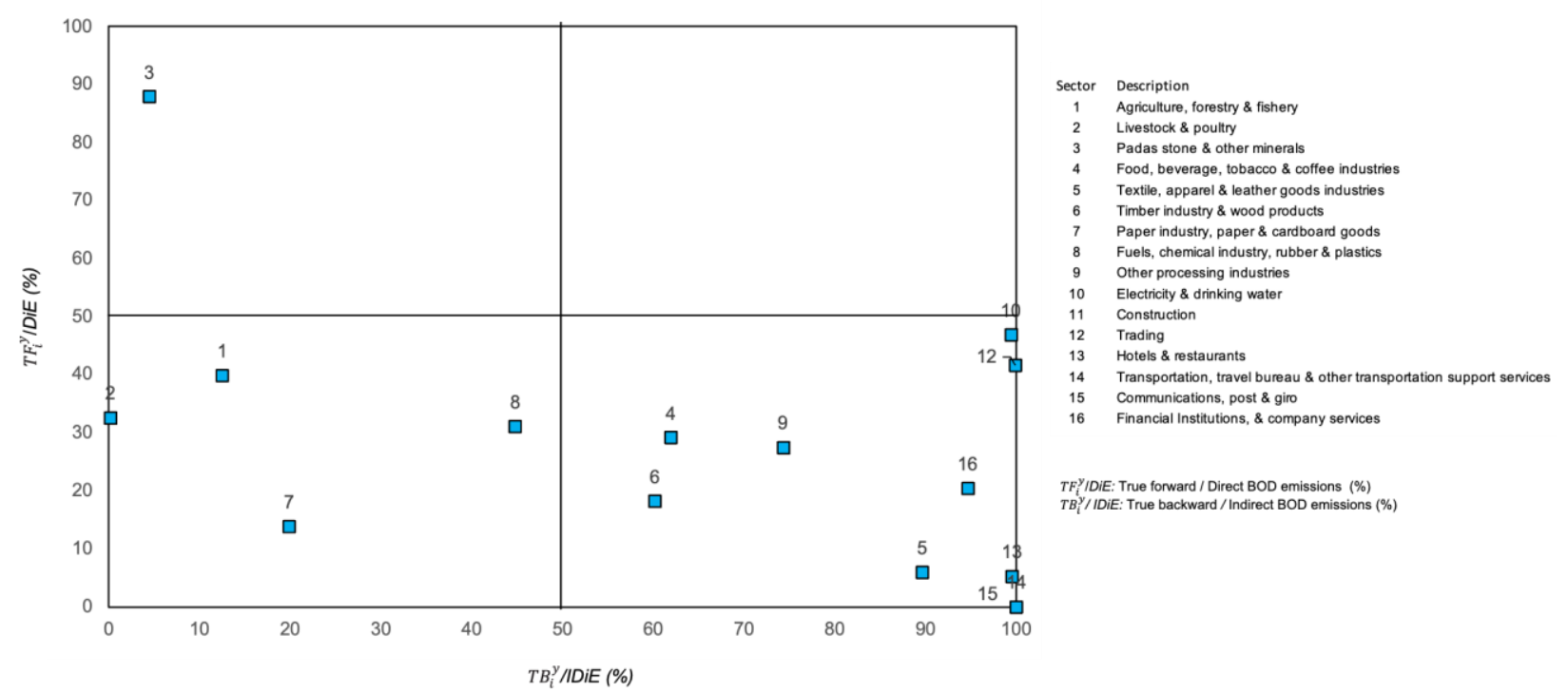

Fig. 6 Classification of sectors based on their BOD emissions characteristics 


\section{$622 \quad$ List of Tables}

623 Table 1 Schematic representation of a conventional I-O table.

624

\begin{tabular}{|c|c|c|c|c|c|c|c|}
\hline \multirow{2}{*}{$\begin{array}{l}\text { Sector } \\
(\text { Seller }) i \\
\end{array}$} & \multicolumn{5}{|c|}{ Intermediate sector } & \multirow[b]{2}{*}{$\begin{array}{l}\text { Final } \\
\text { demand }\end{array}$} & \multirow[b]{2}{*}{$\begin{array}{l}\text { Total } \\
\text { output }\end{array}$} \\
\hline & 1 & $\cdots$ & $j$ & $\ldots$ & $n$ & & \\
\hline 1 & $x_{11}$ & $\ldots$ & $x_{1 j}$ & $\ldots$ & $x_{1 n}$ & $d_{1}$ & $x_{1}$ \\
\hline . & . & $\cdots$ & & $\cdots$ & & & \\
\hline · & . & $\cdots$ & & $\cdots$ & & & \\
\hline$i$ & $x_{i 1}$ & ... & $x_{i j}$ & $\cdots$ & $x_{i n}$ & $d_{i}$ & $x_{i}$ \\
\hline . & . & $\cdots$ & & $\cdots$ & & & \\
\hline$\cdot$ & . & $\cdots$ & & $\cdots$ & & & \\
\hline $\mathrm{n}$ & $x_{n 1}$ & ... & $x_{n j}$ & $\ldots$ & $x_{n n}$ & $d_{n}$ & $x_{n}$ \\
\hline Value added & $v_{l}$ & $\ldots$ & $V_{j}$ & $\ldots$ & $v_{n}$ & & \\
\hline Imports & $m_{1}$ & $\ldots$ & $m_{j}$ & $\ldots$ & $m_{n}$ & & \\
\hline Total inputs & $x_{1}$ & $\ldots$ & $x_{j}$ & $\ldots$ & $x_{n}$ & & \\
\hline
\end{tabular}

625 
Table 2 Extended I-O table.

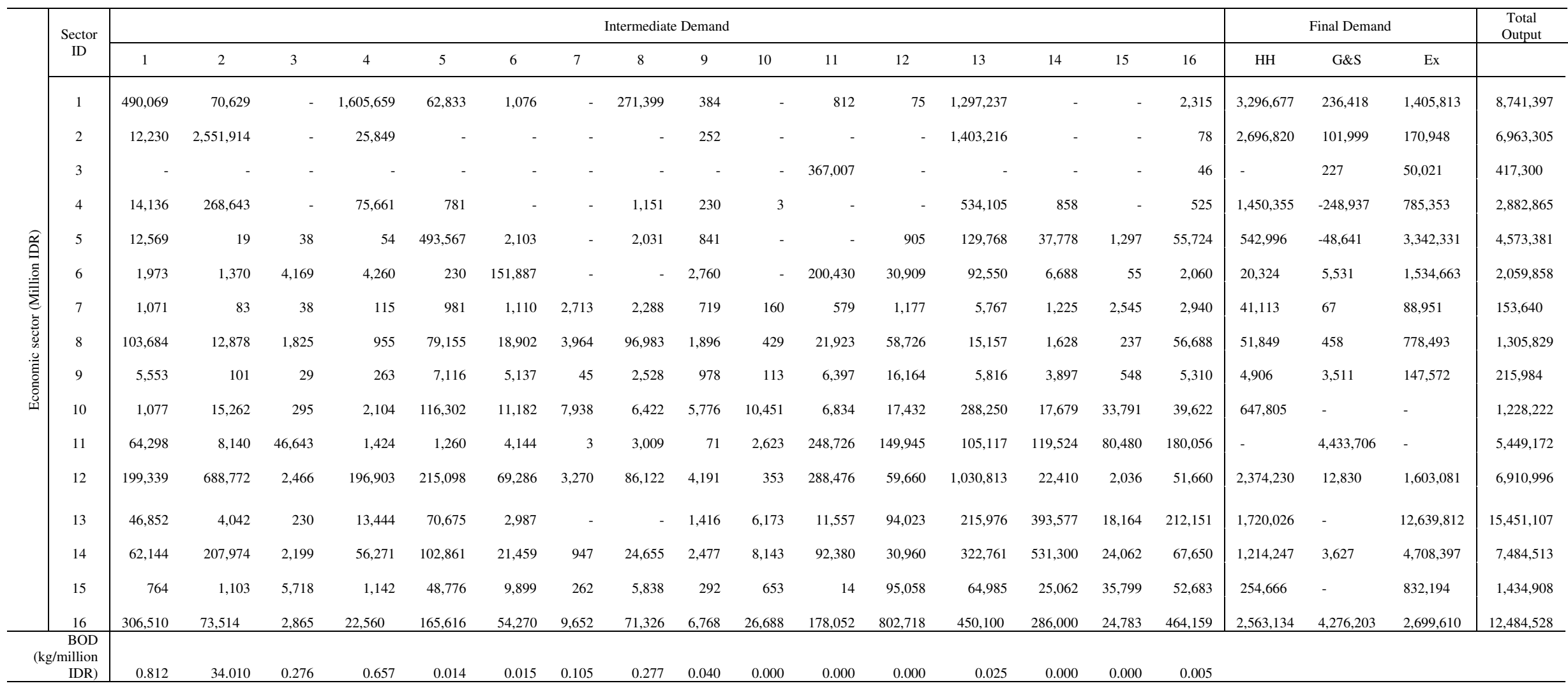

\section{Sector Description}

Agriculture, forestry, \& fishery

Livestock \& poultry

Padas stone \& other minerals

Food, beverage, tobacco, \& coffee industries

Textile, apparel, \& leather goods industries

Timber industry, \& wood products

Paper industry, paper, \& cardboard goods

Fuels, chemical industry, rubber, $\&$ plastics

Other processing industries

Electricity \& drinking water

\section{Construction}

Trading

Hotels \& restaurants

Transportation, travel bureau, \& other transportation support services

Communications, post, \& giro

Financial institutions \& company services

Household consumption

G\&C Gross fixed capital and stock change

Ex Export


Table 3 Matrix of BOD $(\mathrm{kg})$ flow in the economy.

\begin{tabular}{|c|c|c|c|c|c|c|c|c|c|c|c|c|c|c|c|c|}
\hline $\begin{array}{l}\text { Sector } \\
\text { ID } \\
\end{array}$ & 1 & 2 & 3 & 4 & 5 & 6 & 7 & 8 & 9 & 10 & 11 & 12 & 13 & 14 & 15 & 16 \\
\hline 1 & $4,271,454.1$ & $135,375.3$ & 61.8 & $985,474.1$ & $74,304.2$ & $4,529.4$ & 711.7 & $162,216.4$ & 758.7 & 433.0 & $7,873.6$ & $13,838.6$ & $1,379,795.0$ & $34,546.0$ & $1,724.7$ & $28,449.6$ \\
\hline 2 & $581,348.1$ & $159,642,177.2$ & 488.3 & $1,189,520.3$ & $409,447.6$ & $28,480.4$ & $1,613.9$ & $37,589.1$ & $16,625.5$ & $19,070.0$ & $114,257.0$ & $331,609.2$ & $71,781,314.7$ & $1,709,937.8$ & $80,402.5$ & $879,231.9$ \\
\hline 3 & 906.6 & 443.8 & $13,977.0$ & 322.7 & 303.3 & 128.0 & 5.5 & 130.6 & 6.0 & 34.8 & $87,253.2$ & $1,954.3$ & $3,278.4$ & $2,195.3$ & $1,248.9$ & $2,961.6$ \\
\hline 4 & $7,103.0$ & $122,915.8$ & 3.0 & $1,343,289.3$ & $2,892.9$ & 177.3 & 12.2 & 892.3 & 159.2 & 108.1 & 671.1 & $1,890.6$ & $398,284.1$ & $9,996.8$ & 449.6 & $5,197.1$ \\
\hline 5 & 143.5 & 30.1 & 0.2 & 42.3 & $59,692.5$ & 34.1 & 0.9 & 33.6 & 10.4 & 2.0 & 30.1 & 57.2 & $2,043.5$ & 569.0 & 21.5 & 721.8 \\
\hline 6 & 66.0 & 76.9 & 12.1 & 82.2 & 42.6 & $25,837.8$ & 0.5 & 11.4 & 33.8 & 1.7 & $2,935.6$ & 375.2 & $1,696.2$ & 209.2 & 45.1 & 151.2 \\
\hline 7 & 95.8 & 31.1 & 0.8 & 37.5 & 145.2 & 107.4 & $13,926.4$ & 177.1 & 56.8 & 10.0 & 90.0 & 115.3 & 711.1 & 145.8 & 215.3 & 285.1 \\
\hline 8 & $19,396.1$ & $4,691.0$ & 78.7 & $5,147.1$ & $23,482.0$ & $4,904.0$ & $1,044.7$ & $248,654.7$ & 446.1 & 98.8 & $7,601.1$ & $11,267.7$ & $17,246.0$ & $1,655.9$ & 245.3 & $14,371.1$ \\
\hline 9 & 161.8 & 63.2 & 0.6 & 61.5 & 309.5 & 178.9 & 2.4 & 84.1 & $6,292.4$ & 3.1 & 276.0 & 403.9 & 450.6 & 161.8 & 22.9 & 199.2 \\
\hline 10 & 0.7 & 2.5 & 0.0 & 0.6 & 21.7 & 1.9 & 1.3 & 1.0 & 0.8 & 122.8 & 1.9 & 2.9 & 55.5 & 4.7 & 5.1 & 7.3 \\
\hline 11 & - & - & - & - & - & - & - & - & - & - & - & - & - & - & - & - \\
\hline 12 & 12.7 & 46.1 & 0.1 & 16.6 & 20.8 & 5.6 & 0.3 & 6.2 & 0.3 & 0.1 & 24.8 & 379.8 & 122.7 & 5.7 & 0.7 & 6.8 \\
\hline 13 & 927.9 & 559.9 & 2.5 & 585.3 & $2,050.9$ & 141.7 & 7.9 & 111.7 & 34.0 & 97.1 & 577.2 & $1,682.9$ & $365,978.0$ & $8,713.8$ & 409.6 & $4,457.4$ \\
\hline 14 & - & - & - & - & - & - & - & - & - & - & - & - & - & - & - & - \\
\hline 15 & - & - & - & - & - & - & - & - & - & - & - & - & - & - & - & - \\
\hline 16 & $1,164.8$ & 684.4 & 3.9 & 469.1 & $1,116.0$ & 302.5 & 50.9 & 364.7 & 32.3 & 81.9 & $1,102.5$ & $2,678.6$ & $3,937.2$ & $1,507.0$ & 137.2 & $53,217.2$ \\
\hline
\end{tabular}

\begin{tabular}{clll}
\hline Sector & Description & & \\
1 & Agriculture, forestry, \& fishery & 9 & Other processing industries \\
2 & Livestock \& poultry & 10 & Electricity \& drinking water \\
3 & Padas stone \& other minerals & 11 & Construction \\
4 & Food, beverage, tobacco, \& coffee industries & 12 & Trading \\
5 & Textile, apparel, \& leather goods industries & 13 & Hotels \& restaurants \\
6 & Timber industry \& wood products & 14 & Transportation, travel bureau \& other transportation support services \\
7 & Paper industry, paper, \& cardboard goods & 15 & Communications, post, \& giro \\
8 & Fuels, chemical industry, rubber, \& plastics & 16 & Financial institutions \& company services
\end{tabular}


632 Table 4 Disaggregated sectoral pollution components with BOD loads (in tons).

\begin{tabular}{|c|c|c|c|c|c|}
\hline Sector & $\begin{array}{l}\text { Own pollution } \\
\left(O W_{i}^{y}\right)\end{array}$ & $\begin{array}{l}\text { Semi-own pollution } \\
\left(S O W_{i}^{k}\right)\end{array}$ & $\begin{array}{l}\text { True forward } \\
\text { pollution }\left(T F_{i}^{y}\right)\end{array}$ & $\begin{array}{l}\text { True backward } \\
\text { pollution }\left(T B_{i}^{y}\right)\end{array}$ & $\begin{array}{l}\text { Final demand } \\
\text { pollution }\left(F D_{i}^{y}\right)\end{array}$ \\
\hline 1. Agriculture, forestry, \& fishery & 240 & 22.5 & 2,830 & 611 & 4,012 \\
\hline 2. Livestock \& poultry & 58,506 & 134.2 & 77,181 & 265 & 101,002 \\
\hline 3. Padas stone \& other minerals & & 0.1 & 101 & 1 & 14 \\
\hline 4. Food, beverage, tobacco, \& coffee industries & 35 & 2.7 & 551 & 2,182 & 1,305 \\
\hline 5. Textile, apparel, \& leather goods industries & 6 & 0.0 & 4 & 514 & 53 \\
\hline 6. Timber industry \& wood products & 2 & 0.0 & 6 & 39 & 24 \\
\hline 7. Paper industry, paper, \& cardboard goods & 0 & 0.0 & 2 & 3 & 14 \\
\hline 8. Fuels, chemical industry, rubber, \& plastics & 18 & -0.2 & 112 & 202 & 230 \\
\hline 9. Other processing industries & 0 & 0.0 & 2 & 18 & 6 \\
\hline 10. Electricity \& drinking water & 0 & 0.0 & 0 & 20 & 0 \\
\hline 11. Construction & - & 0.0 & - & 223 & - \\
\hline 12. Trading & 0 & 0.0 & 0 & 366 & 0 \\
\hline 13. Hotels \& restaurants & 0 & 7.0 & 20 & 73,589 & 359 \\
\hline $\begin{array}{l}\text { 14. Transportation, travel bureau, \& other } \\
\text { transportation support services }\end{array}$ & - & 0.0 & - & 1,770 & - \\
\hline 15. Communications, post, \& giro & - & 0.0 & - & 85 & - \\
\hline 16. Financial institutions \& company services & 0 & 2.1 & 14 & 936 & 51 \\
\hline
\end{tabular}




\section{Supplementary Files}

This is a list of supplementary files associated with this preprint. Click to download.

- SupplementaryA.docx 